\title{
The Marketing Mix Element of the Coffee Shop. A Case Study @CoffeeBeanIndo
}

\author{
Yuli Harwani Janfry Sihite* \\ Department of Management, Universitas Mercu Buana, Indonesia
}

\begin{abstract}
The study related to the coffee shop is limited. Therefore this research has the objective to build an attribute of the dataset@CoffeeBeanIndo marketing communication, and Coffee Bean is an emerging coffee shop in Indonesia. The research conducted with extracting the unstructured dataset @CoffeeBeanIndo, further exploratory factor analysis conducted. The data processing start with data preparation, taking out the double posted data. Furthermore, after the data cleaned, an exploratory factor analysis conducted with the Provalis Research software that will expose the insight from the 386 unstructured tweets extracted from @CoffeeBeanIndo. Based on the exploratory research@CoffeeBeanIndo, there are some coffee shop service attributes which are the service of process, products that are perceived by the consumer, the promotion, the physical evidence, price offered, as well as the opinions of consumers about the products they buy.
\end{abstract}

Keywords: @CoffeBeanIndo, Marketing Communication, Unstructured Dataset

DOI: $10.7176 / \mathrm{EJBM} / 11-18-20$

Publication date:June $30^{\text {th }} 2019$

\section{Research Background}

As the world forth biggest producer of coffee, the coffee shop is also growing. Indonesia, in the last five years, ranks four as the country with the most significant export after Brazil, Columbia, and Vietnam (International Coffee Organization, 2019).

Coffee is one of the Indonesian competitive product that opens much employment for the farmer (Mahfud, 2012). Since coffee is one of the valuable Indonesian commodity, coffee contributes a significant revenue for Indonesian GDP. Coffee chain of production related to the farmer, the manufacturing that is processing the coffee, and also the marketing supply chain.

The coffee lifestyle in Indonesia is also growing significantly; drinking coffee is not only for older people. Drinking coffee is a part of the lifestyle, for the millennial, the young generation when they are hanging out with their friends in the mall or the cafe. Since there are so many coffee shops that opened and search for opportunity, the competition between the coffee shop is also proliferating.

Coffee shops are developing a strategy to make the coffee shop enjoyable and attracting customers (Hadiwidjaja, 2014). There are many factors and strategy of the coffee shop to attract the potential buyer, the essential factors that influence the potential customer of the coffee shop are accommodating the lifestyle of the millennial's that are looking for a coffee shop to hang out with their friend.

Some factors related to decoration, the cleanliness, the comfort, also interesting for the targeted consumers (Octaviani, 2013). Some lighting and also the variety of the product quality that the consumer like is also the factors that influence the attractiveness of the coffee shop.

Excellent services and also the excellent quality of coffee influence the consumer appetite and the consumer intention to buy (Haryanto, 2013). Some coffee shop is also developing an ambiance that could make the visitors feel cozy. This ambiance will support good quality and also the essential quality of the coffee and influence the intention of the customer to come again, consuming in the coffee shop. The consumers have different preferences on consuming a coffee, and coffee could influence the mental and also the physical of the consumers, relaxing the consumers and also being a stimulant that boosts the energy to do working activities.

The concept of the coffee shop is also evolving, following market demand and wants. The development of coffee shop services by providing food is a concept that is already necessary. The coffee shop also innovates by providing new services, new menu, and a variety of new food to satisfying the consumer. They keep on modifying the old concepts to accommodate the needs and the wants of the consumers relevant to the target market.

Moreover, the coffee shop is also delivering a unique experience that the consumer will have when they are coming to the coffee shop (Pramudita, 2013). The holistic concept of the coffee shop, proposing not only the quality of the product but also the experience of having a coffee in the coffee shop, the architecture, the way the waiter behave, and also the cup, the table, the process of ordering, and the process of drinking the coffee. There are many innovations created by the coffee shop to make a unique experience.

The potential of the market and also the opportunity to search for profit in the market make many businesspeople interested in the coffee business. Moreover, the potential projected coffee consumption is also increasing (Pangestu \& Suryoko, 2016). In Jakarta, the coffee shop is also growing. The restaurant and also the coffee growing numbers also increasing. Therefore the competition of the coffee shop is not only from the domestic 
coffee shop, but also the incoming coffee shop to change from the foreign countries (Rachmawati, 2011).

Since many attributes influence the consumer preference toward the coffee shop, the research needed to identify the variety of product quality, the factors of the services that influence the appetite and the intention to buy. The research to identify the product quality and also how the customers deciding to choose a coffee shop is needed.

Therefore this research look for varieties of attributes delivered from the coffee shop via the tweet (a) CoffeeBeanIndo unstructured data set. Coffee Bean selected as the unit analysis since Coffee Bean is one of the favorite coffee shops in Indonesia. There is also an availability of tweet data set from the Twitter account (a) CoffeeBeanIndo.

\section{Theoretical Review}

The service quality and product quality is a critical factor for the success of a restaurant (Putro, 2014). Since the services and the product is the main proposition that influences consumer satisfaction, it also influences the consumer attitude (Kotler, 1973).

Nevertheless, some argument also states that even the food quality is the most critical factors for the success of restaurants, ambiance and also the performance of the services are contributing for the consumer enough information power at the restaurant (Wall \& Berry, 2007). A pleasant atmosphere also could influence the customer (Karsono, 2015). A pleasant atmosphere could influence a good emotion that the customer sees and reflect the tangibility aspect of the café. A happy atmosphere called to influence the consumers to spend times and also consuming the product in the restaurant.

The environment and decoration are the factors that make a Kopi Tiam popular in Malaysia. The retailer, architect, and also the interior designer has been specializing manage the coziness of the coffee shop environment (Baker, Levy, \& Grewal, 1992).

The consumer also associating the brand of the store with the Western culture, this factor influences the consumer preference to the coffee shop along with the functional attributes such as the quality of the product, the prices, the interior design of the coffee shop.

\section{Research Method}

The @CoffeeBeanIndo selected to be the unit analysis of this research since Coffee Bean is one of the well-known coffee shops in Indonesia. The unit analysis represents the coffee shop growing industry in Indonesia.

The data extracted from the twitter channel @ CoffeeBeanIndo. The tweet dataset selected from January until December 2017. There are 386 tweets processed that represent the interaction@CoffeeBeanIndo to the netizen.

The data processing start with data preparation, taking out the double posted data (Figure 1). Furthermore, after the data cleaned, the further analysis conducted. The process is an exploratory factor analysis with the Provalis Research software that will expose the insight of these 386 unstructured datasets into selected themes.

\begin{tabular}{|c|c|c|c|}
\hline $\begin{array}{c}\text { Data Extraction } \\
@ \text { CoffeeBeanIndo }\end{array}$ & Data Preparation & \begin{tabular}{|c} 
Exploratory Factor \\
Analysis \\
\end{tabular} & Findings \& Discussion \\
\hline 386 Dataset & $\begin{array}{l}334 \text { Tweet \& } \\
52 \text { ReTweet }\end{array}$ & 6 Themes & Product, Promotion \\
\hline
\end{tabular}

Figure 1. Research Process

The exploratory factor analysis is different compared to confirmatory factor analysis. Exploratory factor analysis is useful to look for relationship within the dataset (Wijanto, 2008). Moreover, this research is not confirmatory research, nevertheless the research searching for relationship within the data (Hair, Anderson, Tatham, \& William, 1998).

There is a lack of theory related to the coffee shop attributes. Therefore the exploratory factor analysis conducted for this research. The Twitter data set will be able to expose the @CoffeeBeanIndo service proposition. Some research had been conducted with the method which are the hospitality (Nugroho, 2018), airline (Nugroho \& Sihite, 2015) (Sihite \& Nugroho, 2017), National Tourism Organization (Sihite \& Nugroho, 2018) (Nugroho \& Sihite, 2018) (Nugroho, 2017), Islamic Bank (Nugroho \& Sihite, 2016), University (Nugroho \& Sihite, 2015a) (Nugroho \& Sihite, 2015b), and the political marketing (Sihite, Assauri, \& Halim, 2018).

The cluster analysis technique for textual dataset analysis conducted in the exploratory factor analysis to expose the main themes from the tweet dataset. The cluster analysis reduces data complexity (Campbell, Pitt, Parent, \& Berthon, 2011). The Provalis Research Software consist of 2 software which is the Wordstat and Simstat, called the QDA Miner. This software selected for the exploratory technique to identify the keywords and the relationship between keywords with the coocurence method (Silver \& Lewins, 2014).

\section{Results and Discussion}

The research explores the attributes of a coffee shop that are developing in Indonesia, which is Coffee Bean. The 
tweet analyzed in the research extracted from the official Coffee Bean twitter account that is the corpus delivered to the target consumer.

There are 6 themes from the exploratory factor analysis findings (Figure 2). The themes related to input, critics, recommendation, promotion, and question delivered from the customer to the Coffee Bean. Therefore this research will analyze the existing communication related between the customer and the producer.

On February 3, 2017, an account @windyuchica asking about the branch of Coffee Bean in Surabaya. The tweet is asking about the place when they want to consume the Coffee Bean. Moreover, the Coffee Bean respond if the consumer wants the detail of the place, the customer could open the Coffee Bean website and locate every Coffee Bean in Surabaya.

On 22 May 2017, an account @Jenaka76 delivering a complaint regards to the services. The unsatisfying services in the new Coffee Bean store. Moreover, the next day, Coffee Bean replying and delivering an apology, promising to process the complaint. Coffee Bean tweeting hey, sorry for the inconvenience, we will process the complaint to the related store. We hope to see you again on your next visit.

On 11 June 2017, Coffee Bean receiving input from@dreclarkson because of the empty of the beverage stock. It is related to the store in Banjarmasin, Kalimantan. Two days after, Coffee Bean is delivering an apology for the inconvenience. Coffee Bean sorry for the inconvenience, and will process to the related store.

Another customer@ichaluchal was delivering a complaint because the product that @uchalichal bought in terminal B Adi Soetjipto is expired. Hearing this complaint, Coffee Bean directly delivering an apology and promised the complaint to be processed, Coffee Bean also encourages the customer to keep on coming to the Coffee Bean store.

On 10 June 2017, Coffee Bean promoting a new variant, avocado ice blended. The product has good wording that the consumer could read and interested to buy. Coffee Bean tweeting, one of the benefits of avocado is reducing stress. Let's relax your mind with a glass of avocado ice blended.

Another product promotion on that 10 January 2017 is the information about the beef roll and Americano as the breakfast menu for 33,000 rupiahs. The promotion also includes photos of the beverage packages.

The account qqXOIX on the 10 February 2017 delivering information to the social media user that Coffee Bean is collaborating with PegiPegi providing a free ticket to RajaAmpat. There is also a requirement to get this free ticket. @coffebean_indo said who want to go to the Raja Ampat? Moreover, this tweet having a good response from the netizen.

In the promotion context, on November 13, 2017, Coffee Bean cooperating with GOJEK to earn a mutual benefit, by redeemed GoPoints, The customer could get a discount for 15,000 rupiahs for a promoted drink. The tweet delivered by Coffee Bean state let's redeem 120 GoPoints for and enjoy the ice blended green tea, mocha and pure vanilla with a 15,000 rupiah discount.

@tcash_id is also delivering information on November 6, 2017, delivering a promotion to use the tcash in Coffee Bean store. Get 50\% discount for all products, and it is available only on Monday. The tweet from the official account of the tcash is also delivering a discount for the other day for $10 \%$.

A promotion on July 6, 2017, for celebrating the anniversary of BNI, they're cooperating with Coffee Bean, proposing a discount for the credit and debit card holder. The promotion available for all Coffee Bean store, available for the date selected date. The information acceptance is good from the netizen and earns many likes.

It is not only promotion, a quiz collaborating with transTV on 20 March 2017 state that netizen can win the quiz by making a selfie in front of the TV and answering a question regards to the name of the actor in the Trans TV show. You will get the Coffee Bean voucher. Moreover, there are also many enthusiast netizens responding to the quiz.

On 31 January 2017, and account @atika_u asking about the promotion from the Coffee Bean in paprika point. Coffee Bean directly answers the question, hi for the detail of the paprika promotion, please check in the paprika application.

Coffee Bean is not only selling coffee, but there is also food in the Coffee Bean. In the posting on 14 January 2017, there is a photo that is sent by Coffee Bean with a caption sport is essential. However, good food is also important. Let's enjoy the classic Caesar salad to keep your body healthy.

On 13 January $2017 @$ justpambudi delivering his comment regards to his impression after trying the food in the Coffee Bean. I taste the food at the Coffee Bean, the roasted baby chicken is delicious, the chicken is sweet, and the mushroom sauce is good, it makes good of my time while I am waiting for my wife.

There is also post related to the store that an account@mastio2001 delivered on October 11, 2017. Hang out with a reasonable price at Coffee Bean and bankmega ID. This comment was delivering good value for money for the services and the price offered by the Coffee Bean.

There are some interesting findings from the exploratory of the unstructured data set. Coffee Bean is using the @CoffeeBeanIndo to relate with a customer. The customer is complaining regards to the services, the availability of the food, beverages and also asking information regards to the promotion. The conversation on Twitter is a good way of communicating and maintaining a relationship with consumers. Nevertheless, Coffee 
Bean answering the same way of communication for complaint, by saying that we are sorry and we will process the complaint.

Since the services offered is food and beverage; therefore the process of the consumption is only related until the consumption process end. It started when they see the promotion, booking, or ordering the product at the Coffee Bean store, and also enjoying the products and services in the Coffee Bean store. Nevertheless, the answer is sufficient enough as the services ended after the consumption in the store finish.

Coffee Bean is also cooperating with the other sister company of Trans. Therefore we could see that there are promotions cooperating with Bank Mega and also Tans Studio. This collaboration adds additional value compare with the other coffee shop. Moreover, this is one of the unique characters of the promotion activities delivered by Coffee Bean.

The promotion related to the product information and innovation of the food and the beverage delivered by Coffee Bean. There is also a Photos and the prices of the products. The social media enhanced the promotion delivery to the target consumers. The appealing photos also influenced the interest of the consumers to try the new product.

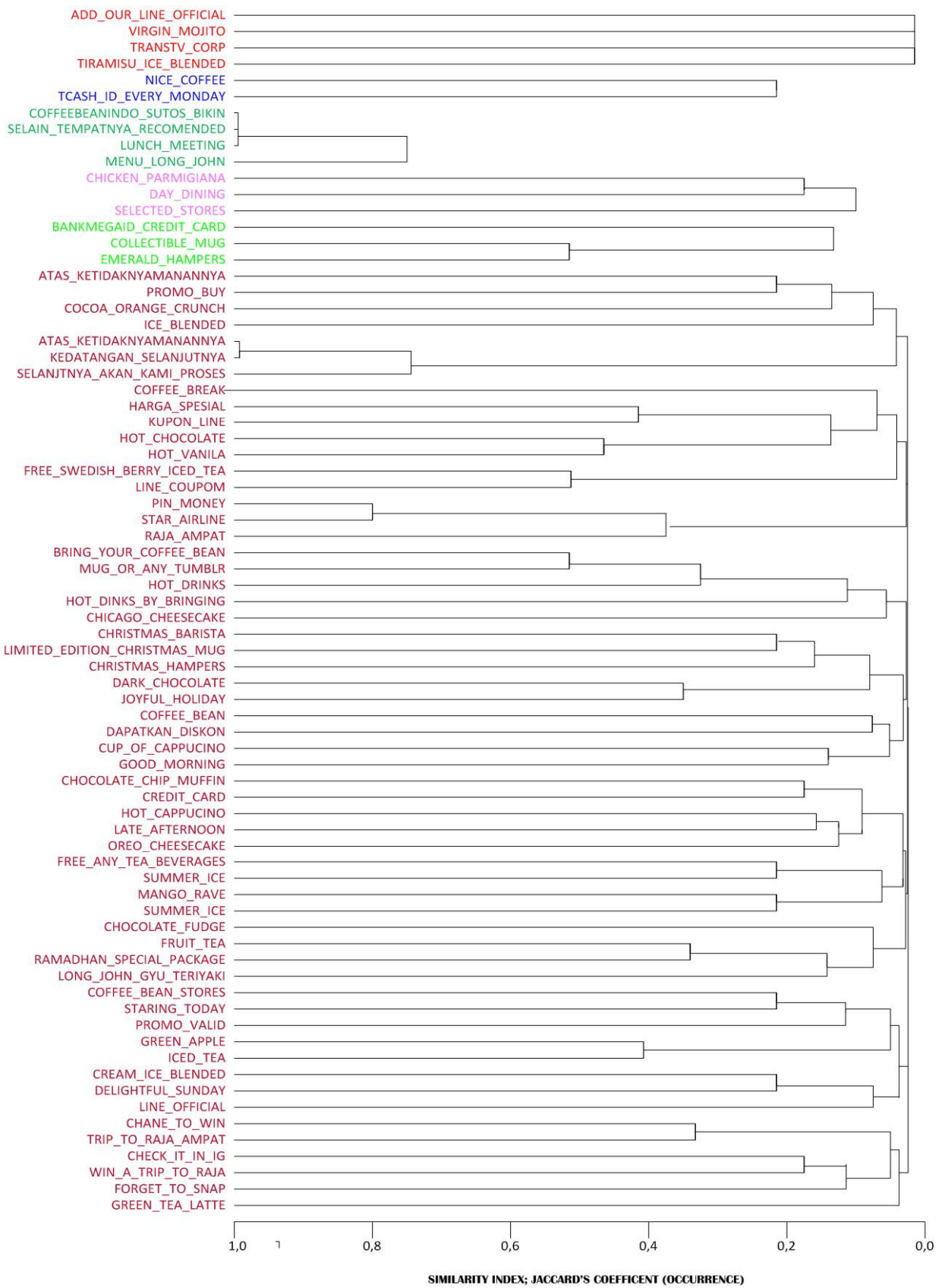

Figure 2. Dendogram@CoffeeBeanIndo 


\section{Conclusion}

Coffee Bean is using social media to enhance the relational benefit and relate to the targeted market. (a) CoffeeBeanIndo deliver information related to the product, price, promotion, place, and also complaint delivered @coffeebeanIndo.

The future research should also improve, how the pictures and photos posted in Coffee Bean compare with the other coffee shop, how the conversation related to complaint handled effectively, therefore we could see varieties of attributes and complaint delivered by the consumers.

Focusing on the complaint in a more extended period of observation will show the attributes characteristic of complaints@CoffeeBeanIndo. Moreover, this will be beneficial to see whether there is an improvement in the service delivery and also the improvement in the satisfaction of the consumers based on the characteristics of the complaint.

\section{References}

Baker, J., Levy, M., \& Grewal, D. (1992). An experimental approach to making retail store environmental decisions. Journal of Retailing, 68(4), 445.

Campbell, C., Pitt, L. F., Parent, M., \& Berthon, P. (2011). Tracking Back-Talk in Consumer-Generated Advertising: An Analysis of Two Interpretative Approaches. Journal of advertising research, 51(1), 224. doi:10.2501/jar-51-1-224-238

Hadiwidjaja, R. S. (2014). Analisa Hubungan Experiential Marketing, Kepuasan Pelanggan, Loyalitas Pelanggan Starbucks Coffee di Surabaya Town Square. Jurnal Strategi Pemasaran, 2(2), 1-11.

Hair, J. F., Anderson, R. E., Tatham, R. L., \& William, C. (1998). Multivariate data analysis.

Haryanto, E. (2013). Kualitas layanan, fasilitas dan harga pengaruhnya terhadap kepuasan pengguna jasa layanan pada kantor samsat Manado. Jurnal EMBA: Jurnal Riset Ekonomi, Manajemen, Bisnis dan Akuntansi, 1(3).

International Coffee Organization, I. (2019). Total Production Statistics. Retrieved from: http://www.ico.org/new historical.asp?section=Statistics

Karsono, B. (2015). Pengaruh Atribut Aksesibilitas dan Keakraban Fisik Ruang kepada Ikatan Tempat.

Kotler, P. (1973). Atmospherics as a marketing tool. Journal of Retailing, 49(4), 48-64.

Mahfud, M. C. (2012). Teknologi dan strategi pengendalian penyakit karat daun untuk meningkatkan produksi kopi nasional. Pengembangan Inovasi Pertanian, 5(1), 44-57.

Nugroho, A. (2017). ASEAN Tourism Marketing Communication Attribute: An Exploratory Research at Goaseantv. European Research Studies Journal, XX(3).

Nugroho, A. (2018). The Hospitality Marketing Communication Attribute. A Case Study@hrhbali (Hard Rock Hotel Bali). Journal of Marketing and Consumer Research, 50.

Nugroho, A., \& Sihite, J. (2015a). Is It A Relational Marketing Strategy? Cluster Analysis (a) Universitasmercubuanajakarta Facebook Post and Comment. Manajemen MIX, V(2).

Nugroho, A., \& Sihite, J. (2015b). Is It Traditional or Contemporary Marketing Strategy? A Textual Cluster Analysis@MercuBuana Reg. Mediterranean Journal of Social Sciences, VI(5).

Nugroho, A., \& Sihite, J. (2015). Tweeting And Retweeting Tourism And Airline Service Attributes. Thomson Reuter Indexed Proceeding. International Geographical Union \& Lombok International Conference. University Mataram.

Nugroho, A., \& Sihite, J. (2016). Exploratory Factor Analysis Syariahmandiri and Bankmandiri Service Attributes 2015. . The Social Sciences, 11, 4896-4901.

Nugroho, A., \& Sihite, J. (2018). ASEAN Tourism Destination: A Strategic Plan. European Research Studies Journal, 21(3), 293-298.

Octaviani, A. (2013). Pengaruh Store Atmosphere Terhadap Keputusan Pembelian Konsumen Coffe Toffe Jatim Expo Surabaya. Jurnal Pendidikan Tata Niaga (JPTN), 1(2).

Pangestu, S. D., \& Suryoko, S. (2016). Pengaruh Gaya Hidup (Lifestyle) Dan Harga Terhadap Keputusan Pembelian (Studi Kasus Pada Pelanggan Peacockoffie Semarang). Jurnal Administrasi Bisnis, 5(1), 63-70.

Pramudita, Y. A. (2013). Analisa pengaruh customer value dan customer experience terhadap customer satisfaction di De Kasteel Resto Surabaya. Jurnal Strategi Pemasaran, 1(1).

Putro, S. W. (2014). Pengaruh Kualitas Layanan dan Kualitas Produk Terhadap Kepuasan Pelanggan dan Loyalitas Konsumen Restoran Happy Garden. Jurnal Strategi Pemasaran, 2(1), 1-9.

Rachmawati, R. (2011). Peranan bauran pemasaran (marketing mix) terhadap peningkatan penjualan (sebuah kajian terhadap bisnis restoran). Jurnal Kompetensi Teknik, 2(2).

Sihite, J., Assauri, S., \& Halim, R. E. (2018). Brand Promise and Reputation Against the Campaign of a Political Party. European Research Studies, 21, 227-240.

Sihite, J., \& Nugroho, A. (2017). Brand Extension In The Marketspace Journal of Economic \& Management Perspectives, 11(3).

Sihite, J., \& Nugroho, A. (2018). Exploring the Indonesian Tourism Destination via Indonesia.Travel @indtravel. 
Silver, C., \& Lewins, A. (2014). Using software in qualitative research: a step-by-step guide.

Wall, E. A., \& Berry, L. L. (2007). The combined effects of the physical environment and employee behavior on customer perception of restaurant service quality. Cornell Hotel and Restaurant Administration Quarterly, 48(1), 59-69.

Wijanto, S. H. (2008). Structural Equation Modeling dengan LISREL 8.8: Konsep dan Tutorial. 